\title{
Language Attitudes Towards Spanish and English in Puerto Rico
}

\author{
Melvin González-Rivera
}

González-Rivera, M. (2021). Language Attitudes Towards Spanish and English in Puerto Rico. Revista de Filología y Lingüística de la Universidad de Costa Rica, 47(2), e47006. doi: https://doi.org/10.15517/rfl.v47i2.47006

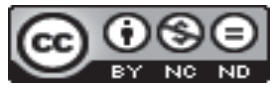

Doi: https://doi.org/10.15517/rfl.v47i2.47006

URL: https://revistas.ucr.ac.cr/index.php/filyling/index 
Revista de Filología y Lingüística de la Universidad de Costa Rica

ISSN: 0377-628X

ISSN: 2215-2628

filyling@gmail.com

Universidad de Costa Rica

Costa Rica

\section{Language Attitudes Towards Spanish and English in Puerto Rico}

González-Rivera, Melvin

Language Attitudes Towards Spanish and English in Puerto Rico

Revista de Filología y Lingüística de la Universidad de Costa Rica, vol. 47, núm. 2, e47006, 2021

Universidad de Costa Rica, Costa Rica

Disponible en: https://www.redalyc.org/articulo.oa?id=33266553015

DOI: https://doi.org/10.15517/rfl.v47i2.47006

\section{(c) (1) $\Theta$}

Esta obra está bajo una Licencia Creative Commons Atribución-NoComercial-SinDerivar 3.0 Internacional. 


\title{
Language Attitudes Towards Spanish and English in Puerto Rico
}

Actitudes lingüísticas hacia el español y el inglés en Puerto Rico

Melvin González-Rivera

Universidad de Puerto Rico, Mayagüez, Puerto Rico

melvin.gonzalez@upr.edu

DOI: https://doi.org/10.15517/rfl.v47i2.47006

Redalyc: https://www.redalyc.org/articulo.oa?

iD https://orcid.org/0000-0001-9630-7338

id $=33266553015$

Recepción: 17 Abril 2020

Aprobación: 29 Junio 2020

\begin{abstract}
:
This article analyzes language attitudes towards Spanish and English in Puerto Rico, a U.S. territory since 1898, and seek to answer the following three questions: are Spanish and English conflicting elements in the Puerto Rican society? Is Spanish a symbol of identity for Puerto Ricans? Does bilingualism represent a threat to the ethno-sociolinguistic existence of Puerto Ricans? By examining an online questionnaire on language attitudes completed by participants living in Puerto Rico, I argue that for Puerto Ricans bilingualism is becoming more prevalent and many of them are increasingly accepting both languages, Spanish and English, without questioning or denying the fact that Spanish is their mother tongue.
\end{abstract}

KEYWORDS: language policy, linguistic legislation, Puerto Rico, bilingualism, language attitudes.

\section{RESUMEN:}

Este artículo analiza las actitudes lingüísticas hacia el español y el inglés en Puerto Rico, territorio de los Estados Unidos desde 1898, y busca responder las siguientes tres preguntas: ¿son el español y el inglés elementos conflictivos en la sociedad puertorriqueña?, ¿es el español un símbolo de identidad para los puertorriqueños?, y ¿el bilingüismo representa una amenaza para la existencia etno-sociolingüística de los puertorriqueños? A través de un cuestionario en línea sobre actitudes lingüísticas completado por participantes que viven en Puerto Rico, propongo que para los puertorriqueños el bilingüismo es cada vez más frecuente y muchos de ellos están aceptando cada vez más ambos idiomas, el español y el inglés, sin cuestionar ni negar el hecho de que el español sea su lengua nativa.

Palabras ClaVe: política lingüística, legislación lingüística, Puerto Rico, bilingüismo, actitudes lingüísticas.

"In Puerto Rico, English was the novel language, and the United States the imposed culture" (Lozano, 2018, p. 248).

\section{INTRODUCTION}

Spanish and English are both official languages in Puerto Rico since 1993. This political decision has generated many debates and multiple discussions given the issues of identity, resistance, repression, mobility, social and economic opportunities, and cultural clashes that the history of these two languages raises in the island (Delgado Cintrón, 1989; Negrón de Montilla, 1990; Pousada, 2008; Ríos Ávila, 1995; Rivera Ramos, 2007; Shenk, 2015; Valdez, 2016). While nowadays many Puerto Ricans are bilinguals, Puerto Rico cannot be considered a bilingual society (Carroll, 2009, 2016; González-Rivera \& Ortiz López, 2018; López Laguerre, 1997). What is more striking if compared to other jurisdictions in the United States, whether in the mainland (California, Texas, Colorado, New Mexico, Arizona) or offshore (Hawaii, Guam, Northern Marina Islands, American Samoa) (cf. Balestra, Martínez \& Moyna, 2008; Faingold, 2019), is that Spanish has been acquired and maintained as the L1 of the inhabitants of the island, whereas English has not been learned as L2 in spite of its prestige as a lingua franca and its educational value and prospects for upward 
social mobility (Schweers \& Vélez, 1992; Torres González, 2002; Vélez, 2000; cf. Grin, 2008; Mari Acevedo, 2017). Contrary to New Mexico, a territory with a high number of Spanish speakers prior to becoming a state of the Union in 1912, and where its government and schools operate in English after the state's legislature decision to endorse it as the language of instruction (Lozano, 2018, p. 233), Puerto Rico can be considered a Latin American and Caribbean country (Morris, 1995; Ateneo Puertorriqueño, 1993, 1996; Rivera Ramos, 2007), a "sociological nation" albeit not a sovereign state, with Spanish as the de facto language of the archipelago. In this paper I examine language attitudes towards Spanish and English in Puerto Rico, and seek to answer the following questions:

a) Are Spanish and English conflicting elements in the Puerto Rican society?

b) Nowadays, is Spanish a symbol of identity for Puerto Ricans?

c) Does bilingualism represent a threat to the ethno-sociolinguistic existence of Puerto Ricans?

The rest of the paper is structured as follows: section 2 is devoted to the history of Spanish and English in Puerto Rico as seen mainly from the linguistic legislation in the island during the $20^{\text {th }}$ and the $21^{\text {st }}$ centuries (Delgado Cintrón, 1994; Muñiz Argüelles, 1999). Sections 3 and 4 analyze language policies in Puerto Rico (Orama, 2011). Section 5 discusses the research questions and Section 7 concludes the essay.

\section{Historical Background: "An American Problem or a Problem for Puerto Rico"}

Puerto Rico is constituted by several islands, located between the Caribbean Sea and the Atlantic Ocean, to the east of the Dominican Republic. The largest of the islands, and the most populated, bears the name of Puerto Rico (Rivera Ramos, 2007). Its history predates the U.S. invasion of 1898: in its origins, the archipelago of Puerto Rico was populated by aboriginal and Taíno groups, whose ethnicity and indigenous language, Arabuaco, disappeared with the advance of the Caribbean colonization by Spain and other European nations during the $15^{\text {th }}$ century and afterwards. Few linguistic influences, sometimes limited to the lexicon, remain in the various Caribbean dialects of such indigenous languages and their people. In the case of Puerto Rico, which was claimed by the Spanish Crown on November $19^{\text {th }}, 1493$, Spanish was converted to the de facto language of the territory, a language forged by four centuries of Spanish colonization (Álvarez Nazario, 1982; Picó, 1988; Silén, 1993). At the time of the U.S. invasion, Puerto Rico was culturally and linguistically a homogeneous society, where few people spoke English or another language (Álvarez González, 1999).

As a consequence of the Spanish-American War, however, the United States invaded Puerto Rico and Spain ceded sovereignty over the island to the United States following the Treaty of Paris on December $10^{\text {th }}$ of 1898 (cf. Guam, Northern Mariana Islands, the U.S. Virgin Islands, and American Samoa). Since, Puerto Rico has been a colony of the United States (Gorrín Peralta, 2015), which may exercise through the U.S. Congress plenary powers over the island and its political affairs, it means that U.S. Congress may legislate over many fundamental aspects of Puerto Rican life (Rivera Ramos, 2007). Thus, constitutionally the United States through its congress has plenary powers over Puerto Rico under the territorial clause of Article IV, section 3, clause 2, of the Constitution (United States Congress, n. d.):

The Congress shall have Power to dispose of and make all needful Rules and Regulations respecting the Territory or other Property belonging to the United States; and nothing in this Constitution shall be so construed as to Prejudice any Claims of the United States, or of any particular State.

The following excerpt from Rivera Ramos (2007, p. 13) describes the current relationship between Puerto Rico and the United States:

Many provisions of the U.S. Constitution apply to Puerto Rico. These include the supremacy clause of Article VI, that prescribes that the Constitution, laws, and treaties of the United States shall be the supreme law of the land; the territorial 
clause of Article IV, granting the U.S. Congress the power to make rules and regulations for the territory or other property of the U.S.; and many of the guarantees of the Bill of Rights. Decisions of the U.S. Supreme Court are binding on the island. In certain circumstances, that court may review decisions rendered by the Supreme Court of Puerto Rico. The U.S. District Court for the District of Puerto Rico and a U.S. Court of Appeals pass judgement over a variety of legal controversies that affect the country's government and population.

Rivera Ramos (2007, p. 15) acknowledges further that Puerto Rico can be considered an overseas possession of the United States, to which is legally, militarily, politically, and economically subordinate, a view that is shared by other legal scholars in the field (Cox Alomar, 2015; Gorrín Peralta, 2015; Rivera Ramos, 2015; Torruella, 2015; among many others). However, Puerto Rico has a distinct nationality, with its own national culture and traditions (Álvarez González, 1999).

This new socio-political reality created a sociolinguistic context non-existent before 1898: the coexistence of Spanish and English. Language policy and planning thus became an issue, which after more than one hundred years of coexistence between Spanish and English has still not been resolved (López Laguerre, 1997; Trías Monge, 1999). The debate has had an impact on various theoretical and methodological approaches: linguistic, political, sociological, historical, and pedagogical (Rúa, 1992; Negrón-Muntaner, 1997; cf. Álvarez González, 1999; Torres González, 2002). Furthermore, the coexistence of both Spanish and English took shape within a social and juridical framework unknown to the majority of the inhabitants of Puerto Rico; but followed nonetheless the common practice in colonial settings: "colonisation gave rise to a (new) language hierarchy in which the language of the coloniser was inscribed as the most prestigious language and came to dominate the administrative and mercantile structure of each colony" (Migge \& Léglise, 2008, p. 301).

The first glimpse of a language policy came by way of the Language Law ("La Ley del Idioma") on February $21^{\text {st }}$ of 1902 (Muniz Argüelles, 1999). In section 1 of the aforementioned law the use of English and Spanish in the Department of the Insular Government, tribunals, and public offices was established:

In all the departments of the Commonwealth government and in all the courts of this island, and in all public offices the English language and the Spanish language shall be used indiscriminately; and, when necessary, translations and oral interpretations shall be made from one language to the other so that all parties interested may understand any proceedings or communications made therein (cf. Álvarez González, 1999, p. 365).

However, the Language Law did not declare official Spanish nor English, but rather decrees their uses interchangeably in various governmental agencies, with exceptions to municipal tribunals and the municipalities. Delgado Cintrón (1989, p. 126) highlights the confusing situation the residents of Puerto Rico were exposed to at the beginning of the $20^{\text {th }}$ century, because there is no linguistic policy that determines the officiality of any or both languages, but only recognition and mandate over the use of both within the administrative aspects and state dispositions. The laws and resolutions approved in the first session of the second Legislative Assembly of Puerto Rico in 1903, which included the Organic Law, reflects this situation: in section 30 of this law, it is established that in order to be a member of the House of Delegates, one of the local legislative bodies, it was necessary to read and write in whichever of the two languages.

The Language Law of 1902 was finally abolished on April $5^{\text {th }}$ of 1991 through the approval of Law No. 4, proposed by then-Governor Rafael Hernández Colón of the pro-Commonwealth Popular Democratic Party ("Partido Popular Democrático"). This law recognized Spanish as the only official language of Puerto Rico. The people of Puerto Rico won the Prince of Asturias Award for having maintained Spanish after 100 years of linguistic and cultural contact with the United States. The motivation behind this law, as expressed in its preamble, was to reaffirm the historical status of Puerto Ricans as Spanish-speaking people. At the same time, it expressed a commitment to acquire English as a second language. However, on January $28^{\text {th }}$ of 1993 , the legislature of Puerto Rico approved Law No. 1, proposed by the-governor Pedro Rosselló González of the opposing and pro-statehood New Progressive Party ("Partido Nuevo Progresista"), establishing through Article 1 that Spanish and English are the official languages on the island and thus abolishing the previous law. 
This approval reestablished the juridical situation that existed in Puerto Rico prior to the sanction of the 1991 law. The motivation to approve this legislation was of a pragmatic nature, as it is clear from the preamble of the law: the political, economic, and social progress of Puerto Rico is intimately linked to having both Spanish and English as official languages of this jurisdiction. This new law maintained, however, the language policy of the Law 68 from August 28 ${ }^{\text {th }}$, 1991: English will be taught as a second language and education will take place in the vernacular, Spanish. A similar view was previously shared by the senators of the Subcommittee on Territories and Insular Affairs which conducted a Senate hearing in Puerto Rico in 1943. Known as the Chávez Committee, in part due to the chair's, Dennis Chávez, proficiency in Spanish (Lozano, 2018), the committee believed that proficiency in English would facilitate financial success and guarantee access to the full rights of U.S. citizenship: "[1] ack of English skills left Puerto Ricans without the ability to easily migrate to the United States, obtain a job on the mainland, or follow their commander as members of the army" (cf. Clachar, 1997; Lozano 2018, p. 249). The Chávez Committee's outcomes, however, turned out to be the opposite of their initial intention: to defend English as the proper culture of anyone living or associated with the United States. Lozano (2018, p. 250) explains the aftermath of the Chávez Committee as follows:

\begin{abstract}
The Chávez Committee's mission to Puerto Rico inadvertently helped solidify Spanish as a permanent part of the territory's national identity. Educators, students, and politicians used language as a political means of distancing themselves from the United States and to advocate for greater autonomy. They did this by coming out in force against the findings and opinions of the committee. Educators wanted local autonomy that would allow them to choose the most appropriate instructional language for their students rather than have it dictated by the federal government. After the hearing, islander's discussions about the relative merits of Spanish and English no longer focused on the potential of bilingual pedagogy but rather on Spanish's central role in Puerto Rican's culture and identity.
\end{abstract}

In sum, the status of the current law in Puerto Rico is similar to that of the beginning of the $20^{\text {th }}$ century: both languages, Spanish and English, are official.

\title{
3. LaCK Of Planning: “...NI ESPANglish Ni ENGaÑol”
}

Salvador Tió, a Puerto Rican poet and writer, warned in 1948 against the 'danger of contamination' or the corruption of the Spanish language and its grammar by the use of English in Puerto Rico (Cardona, 1980; Rodríguez Bou, 1984; Rúa, 1992). This ideology, shared by many intellectuals and scholars (cf. Clachar, 1997; Schweers \& Vélez, 1992; Resnick, 1993), together with the discussion in the previous section show that language planning and policy in Puerto Rico have been seen from a sociopolitical perspective, framed within a socio-historic reality that took place in 1898 with the change of the political sovereignty, as previously discussed. Nowadays, Puerto Rican society is largely monolingual, Spanish is the L1 of the majority of residents on the island, while English is not an L2. The 2010 U.S. Census demonstrates that $66.4 \%$ of the population in Puerto Rico "does not speak English or does not speak English well", and in $95.7 \%$ of the households the language of use is Spanish. In 2008, the percentage of households in which the language of use was Spanish reached $95.1 \%$; only $19.2 \%$ of the residents in the island speak English "very well" and in $4.1 \%$ of the households in Puerto Rico English is primarily spoken, which represents a reduction of $0.7 \%$ in comparison to 2008. Data from the most recent U.S. Census in 2014 show similar results: $44 \%$ of Puerto Ricans do not speak English, $4 \%$ only use English, and the remaining $52 \%$ speak English at varying levels of proficiency (Guzzardo, Loureiro, Fidan \& Vélez, 2019).

The linguistic reality is more complicated if the studies and official reports about the command of certain skills in both languages are taken into consideration. For instance, the report of the Commission of Education, Science and Culture of the Senate of Puerto Rico in 2001 described the failure of the academic system in achieving that the students master verbal and written communication skills in both Spanish and English. Likewise, the Pruebas Puertorriqueñas de Aprovechamiento Académico (PPAA) 2006-2010 show a 
low student's performance in Spanish as well as in English; and the score in the College Board showed a decrease from $470(/ 800)$ in 1985 to 450 (/800) in 1999 (Reyes Tosta, 2013, p. 47).

In sum, the failure in the teaching of both languages could be interpreted as a result of the linguistic conflict between Spanish and English: linking both languages to certain ideologies of cultural assimilation has not permitted an effective educational project in Puerto Rico. Within this ideological context, Spanish has been seen as a symbol of national identity (Shenk, 2015; Valdez, 2016) that serves as a pitfall for the assimilation and annexation to the United States. The ideology in defense of the vernacular goes in hand with a rejection and fear of English.

\section{Linguistic Planning: "Proyecto Para formar un ciudadano bilingüe"}

Linguistic planning in Puerto Rico arises from within this political and ideological debate alluded to in the sections above (cf. Ricento, 2008). The educational system can be divided into two periods: before and after 1948. Before 1948, the elementary grades could offer teaching in Spanish or in English, but studies in secondary and higher education could only be given in English (López Laguerre, 1997; Ortiz López, 2000; Torres González, 2002), according to the public policy by the government, which does not necessarily respond to the linguistic reality of the country. In spite of this, Puerto Rico was considered a bilingual territory, since Spanish and English shared official status (Pousada, 1989), although monolingualism in Spanish prevailed along with bilingualism in various manifestations among its citizens, as previously stated. The language policy from 1948 to the present maintains Spanish as the medium of instruction in all levels of public education. In 1997, the Puerto Rico Department of Education published the Project for Developing a Bilingual Citizen (Proyectopara Formar un Ciudadano Bilingüe), a bilingual initiative which promoted the following (Ortiz López, 2000):

1. Start reading in English and Spanish during elementary school.

2. Allot 90 minutes of instruction in Spanish and in English at the intermediate level of instruction.

3. Use of English to teach science and mathematics.

4. Provide immersion programs in English for high school students, as well as writing workshops in Spanish.

5. Promote opportunities and incentives to teachers who are teaching English, so they may develop professionally and obtain certifications in teaching English.

6. Develop an exchange program that permits Puerto Rican teachers to improve their English skills in the United States and bring North American teachers to Puerto Rico in order to help Puerto Rican teachers on the island to improve their English.

7. Provide technical assistance and give supervision in English and Spanish in all school districts.

Still, there has not been any attempt to examine the qualitative and quantitative data, the scope and achievements of the Project for Developing a Bilingual Citizen. This initiative has, however, various critics from cultural and academic institutions and from center and left-wing politics in the country. These groups have criticized that the definitions of bilingualism were not substantiated in scientific research, but rather in personal opinions, and that the theoretical frameworks of the project were founded in other linguistic and cultural realities. Given such findings, the Puerto Rican Academy of the Spanish Language ('Academia Puertorriqueña de la Lengua Española' or APLE) recommended the following educational policy (Orama, 2011): the use of Spanish as a teaching instrument and initiation of English learning once communication skills in Spanish have been developed, a proposal contrary to the findings of bilingual communities (De Houwer, 2009a, 2009b). APLE, in the first place, defends Spanish as the vernacular language, which serves all social functions of the society of Puerto Rico better than English, from nationalist and cultural perspectives; secondly, APLE proposes the teaching of English as a second language or foreign language, without clearly delineating the differences between the two languages, nor offering a concrete proposal on how to achieve success in both languages, given the current sociolinguistic reality of Puerto Rico. This position does not 
provide a concrete proposal that guarantees the necessary space for both languages, both for the success of Spanish as L1 and English as L2 or foreign language. Moreover, the whole reaction lacks reference to one important aspect of Puerto Rican society, the diaspora in the United States. Today, a language policy should recognize the scientific advances of second language acquisition research and incorporate the Puerto Rican diaspora as part of that language policy.

Torres González (2002) has described "an imperfect language policy" framed in bilingualism, in government, and in teaching which "recognizes the primacy of vernacular Spanish and the importance of English as a second language". This proposal responds to the trends towards globalization, which on one side promotes expansion of lingua francas, like English, and on the other side favors strong tendencies toward cultural and linguistic heterogeneity which manifest not only in ethnic, national, regional or territorial terms, but also in terms of class, gender, generational groups, and other social groups. In sum, Torres González defends a type of additive bilingualism which considers all the components of the Puerto Rican society (cf. Bieswanger, 2008).

Despite the failure on the development of a linguistic policy, especially of English learning, the residents of Puerto Rico have a very positive attitude toward the instruction of this language, without it being necessarily an attack on their ethno-socio-cultural identity (Carroll, Rivera \& Santiago, 2015; Clachar, 2007; Domínguez Rosado, 2012, 2015; Hermina, 2014; Mazak, 2012; Mazak \& Herbas-Donoso, 2014; Pérez Casas, 2008, 2016; Pizarro, 2006; González-Rivera \& Ortiz López, 2018). In the following section, I discuss the findings of a questionnaire which seek information about language attitudes towards Spanish and English, and bilingualism in Puerto Rico.

\section{Language attitudes in Puerto Rico}

Attitudes refer to judgments that people make and generalize about an object outside themselves and are viewed as stable and related to meaningful objects or events (Gallois, Watson \& Brabant, 2008, p. 596; cf. Eagly \& Chaiken, 1993; Vaughan \& Hogg, 2004). Gallois, Watson \& Brabant (2008, p. 596) propose the following three components for the concept of attitude: cognitive, conative (behavioral), and affective. The first one refers to the person's belief and thought about the attitude object, without any positive or negative tone; conative is a predisposition to behave according to such belief; and the affective component represents the emotional reaction that accompanies the beliefs, whether positive or genitive. In this paper, I adhere to this definition of attitudes.

Some studies have shown the positive attitudes Puerto Ricans have towards the instruction of English, while others present a more complex picture of Puerto Ricans attitudes toward Spanish and English (Betancourt, 1976; Domínguez Rosado, 2012, 2015; Guzzardo Tamargo et al., 2019; Rodríguez Galarza, 1997; among others). Carroll, Rivera \& Santiago (2015) carried out a study among students of the University of Puerto Rico, Mayagüez Campus, and found that the younger students in this public institution believe that instruction of English is an important aspect of the college life and experience. Pizarro (2006) had previously carried out a very similar study in the Rio Piedras Campus and found likewise a very favorable attitude toward this language. A study by Hermina (2014) about the instruction of English in two elementary schools in Puerto Rico, one public and the other one private, shows on the hand a very favorable opinion from the parents towards the bilingual instruction of Spanish and English. This very favorable attitude toward English is due to this language being seen as a tool for social mobility.

In order to answer the research questions, I carried out a survey on language attitudes in 39 Puerto Ricans: 29 or $74 \%$ women and 10 or $26 \%$ men, distributed among the following groups:

Age group:

a. $18-25: 31 \%$

b. $26-33: 21 \%$ 


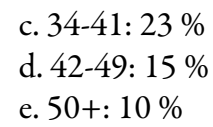

The participants completed an online questionnaire through Qualtrics, a web-based software tool that allows one to create surveys.

All participants indicated speaking both Spanish and English, while $87 \%$ mentioned being born in Puerto Rico, $10 \%$ in the United States and $3 \%$ or the equivalent to one participant elsewhere, specifically in the Dominican Republic. This participant, however, arrived in Puerto Rich in his childhood and his primary and secondary education was on the island. Also, everyone with the exception of one participant indicated having studied English at school.

To the first research question: are Spanish and English conflicting elements in the Puerto Rican society, $61 \%$ of the participants answered Yes. This question was followed by a follow-up question in which the participants were asked to explain their answers. Here are some participant's comments:

-Lamentablemente para muchos lo es, pero entiendo no debería ser un conflicto.

"Unfortunately for many it is, but I understand it should not be a conflict".

-Porque la mitad de nuestro país asocia el bilingüismo al estatus politico.

"Because half of our people associates bilingualism with the political status".

-Para mi no, pero el inglés aqui se ha implementado como herramienta politica y también está relacionado a la posición socioeconómica de la persona.

"Not for me, but English here has been implemented as a political tool and it is also related to the person's socioeconomic status".

The second research question seeks to answer the following: Nowadays, is Spanish a symbol of identity for Puerto Ricans? $86.11 \%$ answer Yes to this question. Some comments were:

-Llevamos bien arraigado nuestra relación histórica con España.

"The historical relationship with Spain is deeply rooted in us".

-Es nuestro idioma.

"It's our language".

-Es el idioma con el cual nos comunicamos cotidianamente y mediante el cual forjamos nuestra identidad cultural.

"We communicate in Spanish on a daily basis and it is the language through which we forge our cultural identity".

Finally, $88.89 \%$ answer No to the last question, namely, does bilingualism represent a threat to the ethnosociolinguistic existence of Puerto Ricans? Some comments follow:

-Los idiomas no deben afectar mi identidad cultural.

"Languages should not affect my cultural identity".

- El hablar dos idiomas no me hace perder mis tradiciones, mi cultura.

"Speaking two languages does not make me lose my traditions, my culture".

- Esa es nuestra identidad cultural del tiempo de ahora.

"That is our cultural identity right of now".

Even though Spanish may be considered a symbol of identity for many Puerto Ricans, who at the same time are fully aware of the linguistic conflicts Spanish and English generate in the island, bilingualism is becoming more prevalent among them, and many Puerto Ricans are increasingly accepting both languages, despite controversies concerning identity and officiality, without questioning or denying the fact that Spanish is their mother tongue, as previously stated (Pabón, 2002). 


\section{Conclusion}

In this essay, I have described the linguistic issue in Puerto Rico from the beginnings of the $20^{\text {th }}$ century to the present day. Language planning and policy in the island have been shaped by the socio-political relationship with the United States. The growing instrumental and economic value of learning English has modified past attitudes and beliefs and allowed the language to penetrate some domains of Puerto Rican society, without becoming a threat to their identity. A viable language policy for Puerto Rico must attend to the island's complex sociolinguistic heterogeneity, including: Puerto Ricans of less privileged classes, who are more monolingual in Spanish; the middle and upper classes, who are more bilingual in Spanish and English; and the Puerto Rican diaspora, some of whom tend to be monolingual in non-standard English.

\section{BiBLIOGRAPHY}

Álvarez González, J. J. (1999). Law, Language, and Statehood: The Role of English in the Great State of Puerto Rico. Law \& Inequality: a journal of theory and practice, 17(2), 359-443.

Álvarez Nazario, M. (1982). Orígenes y desarrollo del español en Puerto Rico (siglos XVI y XVII). Río Piedras, Puerto Rico: Universidad de Puerto Rico.

Ateneo Puertorriqueño. (1993). Comunicado de prensa sobre estudio del Ateneo Puertorriqueño respecto al uso, dominio y preferencia de los idiomas español e inglés en Puerto Rico. San Juan, Puerto Rico: Ateneo.

Ateneo Puertorriqueño. (1996). Puertorriqueños firmes en su idioma español. San Juan, Puerto Rico: Ateneo.

Balestra, A., Martínez, G. \& Moyna, M. I. (2008). Recovering the U.S. Hispanic Linguistic Heritage. In A. Balestra, G. Martínez \& M. I. Moyna (Eds.), Recovering the U.S. Hispanic Linguistic Heritage: Sociohistorical Approaches to Spanish in the United States (pp. 2-72). Houston: Arte Público Press.

Betancourt, F. (1976). Language Attitudes and Language Education in Arecibo, Puerto Rico. (Ph. D. dissertation). The University of Texas at Austin.

Bieswanger, M. (2008). Language and Education. In M. Hellinger \& A. Pauwells (Eds.), Handbook of Language and Communication: Diversity and Change (pp. 401-427). Berlin/New York: Mouton de Gruyter.

Cardona, S. (1980). Defensa de la enseñanza del lenguaje. Boletín de la Academia Puertorriqueña de la Lengua Española, $8(1), 5-16$.

Carroll, K. S. (2009). Language Maintenance in Aruba and Puerto Rico: Understanding Perceptions of Language Threat. (Ph. D. dissertation). University of Arizona.

Carroll, K. S. (2016). Language Policies in Puerto Rican Higher Education: Conflicting Assumptions of Bilingualism. Current Issues in Language Planning, 17(3-4), 260-277.

Carroll, K. S., Rivera, R. L. \& Santiago, K. (2015). Questioning Linguistic Imperialism: Language Negotiation in an Agriculture Classroom. In A. Fabricius \& B. Preisler (Eds.), Transcultural Interaction and Linguistic Diversity in Higher Education (pp. 164-187). New York: Palgrave Macmillan.

Clachar, A. (1997). Student's Reflections on the Social, Political, and Ideological Role of English in Puerto Rico. Hispanic Journal of Behavioral Sciences, 19(4), 461-478.

Clachar, A. (2007). Negotiation of identities through the linguistic structures and the choice of language: Puerto Rican migrants returning to American companies in Puerto Rico. Revista Internacional de Lingüistica Iberoamericana, 5(2), 147-162.

Cox Alomar, R. (2015). The ideological Decolonization of the Puerto Rico's autonomist movement. In G. L. Neuman \& T. Brown-Nagin, Reconsidering the Insular Cases: The Past and Future of the American Empire (pp. 129-166). Cambridge, MA: Harvard Law School.

De Houwer, A. (2009a). Bilingual First Language Acquisition. Clevedon, U. K.: Multilingual Matters.

De Houwer, A. (2009b). An Introduction to Bilingual Development. Clevedon, U. K.: Multilingual Matters. 
Delgado Cintrón, C. (1989). Razones para declarar el idioma español único oficial en Puerto Rico. Revista de Ciencias Sociales, 28(3-4), 125-136.

Delgado Cintrón, C. (1994). El debate legislativo sobre las leyes del idioma en Puerto Rico, 1991 y 1993: materiales introductorios, documentos, proyectos de ley, informes legislativos, ponencias, escritos, fotografias. San Juan, Puerto Rico: Editorial de la Revista del Colegio de Abogados de Puerto Rico.

Domínguez Rosado, B. (2012). Language and Identity: The Study of a Possible Ongoing Change in Attitudes Towards American English and Puerto Rican Spanish in Puerto Rico. (Ph. D. dissertation). Universidad de Puerto Rico.

Domínguez Rosado, B. (2015). The Unlinking of Language and Puerto Rican Identity: New Trends in Sight. Newcastle upon Tyne: Cambridge Scholars.

Eagly, A. H. \& Chaiken, S. (1993). The Psychology of Attitudes. Orlando, FL: Harcourt Brace Jovanovich.

Faingold, E. (2019). Language Rights and the Law in the United States and its Territories. Lanham, MA: Rowman and Littlefield.

Gallois, C., Watson, B. \& Brabant, M. (2008). Attitudes to Language and Communication. In M. Hellinger and A. Pauwells (Eds.), Handbook of Language and Communication: Diversity and Change (pp. 595-618). Berlin/New York: Mouton de Gruyter.

González-Rivera, M. \& L. A. Ortiz López. (2018). El español y el inglés en Puerto Rico: una polémica de más de un siglo. Centro Journal, 30(1), 106-131.

Gorrín Peralta, C. I. (2015). Puerto Rico and the United States at the Crossroads. In G. L. Neuman \& T. BrownNagin, Reconsidering the Insular Cases: The Past and Future of the American Empire (pp. 183-212). Cambridge, MA: Harvard Law School.

Grin, F. (2008). Economics and Language Policy. In M. Hellinger \& A. Pauwells (Eds.), Handbook of Language and Communication: Diversity and Change (pp. 271-298). Berlin/New York: Mouton de Gruyter.

Guzzardo Tamargo, R. E., Loureiro-Rodríguez, V., Fidan Acar, E. \& Vélez Avilés, J. (2019). Attitudes in Progress: Puerto Rican's Youth Opinions on Monolingual and Code-switched Languages Varieties. Journal of Multilingual and Multicultural Development. doi: 10.1080/01434632.2018.1515951

Hermina, J. (2014). Two Different Speech Communities in Puerto Rico: A Qualitative Study about Social Class and Children Learning English in Public and Private Schools of the Island. (Ph. D. dissertation). The University of New Mexico.

López Laguerre, M. A. (1997). El bilingüismo en Puerto Rico. San Juan, Puerto Rico: Espuela.

Lozano, R. (2018). An American Language: The History of Spanish in the United States. Oakland, CA: The University of California Press.

Mari Acevedo, V. Z. (2017). Motivation to Learn and Teach English in Puerto Rico's Public and Private Schools. (Ph. D. dissertation). The University of Texas at San Antonio.

Mazak, C. M. (2012). My Cousin Talks Bad like You: Relationships between Language and Identity in a Rural Puerto Rican Community.Journal of Language, Identity, and Education, 11(1), 35-51.

Mazak, C. M. \& Herbas-Donoso, C. (2014). Translanguaging Practices and Language Ideologies in Puerto Rican University Science Education. Critical Inquiry in Language Studies, 11(1), 27-49.

Migge, B. \& Léglise, I. (2008). Language and Colonialism. In M. Hellinger and A. Pauwells (Eds.), Handbook of Language and Communication: Diversity and Change (pp. 299-332). Berlin/New York: Mouton de Gruyter.

Morris, N. (1995). Puerto Rico: Culture, Politics, and Identity. Westport, CT: Praeger.

Muñiz Argüelles, L. (1999). Las normas puertorriqueñas en relación al uso de las lenguas en el ámbito de la institución registral. Revista Jurídica Universidad Interamericana de Puerto Rico, 34(1), 79-98.

Negrón de Montilla, A. (1990). La americanización de Puerto Rico y el sistema de instrucción pública, 1900-1930. Río Piedras, Puerto Rico: Editorial de la Universidad de Puerto Rico.

Negrón-Muntaner, F. (1997). English only jamás but Spanish only cuidado: Language and Nationalism in Contemporary Puerto Rico. In F. Negrón-Muntaner \& R. Grosfoguel (Eds.), Puerto Rican Jam: Essays on Culture and Politics (pp. 257-285). Minneapolis, MN: University of Minnesota Press. 
Orama, C. (2011). Puerto Rico y sus pugnas lingüísticas. Cuadrivium, 7, 70-80.

Ortiz López, L. (2000). Proyecto para formar un ciudadano bilingüe, política lingüística y el español de Puerto Rico. In A. Roca (Ed.), Research on Spanish in the United States: Linguistic Issues and Challenges (pp. 390-405). Somerville, MA: Cascadilla Press.

Pabón, C. (2002). Nación postmortem: ensayos sobre los tiempos de insoportable ambigüedad. San Juan, Puerto Rico: Callejón.

Pérez Casas, M. (2008). Codeswitching and identity among island Puerto Rican bilinguals. (Ph. D. dissertation). Georgetown University.

Pérez Casas, M. (2016). Codeswitching and identity among island Puerto Rican bilinguals. In R. E. Guzzardo Tamargo, C. M. Mazak \& M. C. Parafita Couto (Eds.), Spanish-English codeswitching in the Caribbean and the US (pp. 37-60). Amsterdam: John Benjamins.

Picó, F. (1988). Historia general de Puerto Rico. San Juan, Puerto Rico: Huracán.

Pizarro, V. G. (2006). The ethnolinguistic identity of the University of Puerto Rico, Rio Piedras campus first year college students and their attitudes towards the learning of English as a Second Language. (Ph. D. dissertation). Universidad de Puerto Rico.

Pousada, A. (1989). La planificación lingüística en Puerto Rico. Plerus, 19(1), 105-116.

Pousada, A. (2008). Functions and valorization of language in Puerto Rico. Centro Journal, 20(1), 4-11.

Resnick, M. C. (1993). ESL and language planning in Puerto Rican education. Tesol Quarterly, 27(2), 259-275.

Reyes Tosta, M. (2013). El aprendizaje del español y del inglés en Puerto Rico y sus influencias extranjeras. Scientific International Journal, 10(3), 44-53. Retrieved from http://www.nperci.org/M.\%20Reyes-EspIng-V10N3.pdf

Ricento, T. (2008). Models and approaches in language policy and planning. In M. Hellinger \& A. Pauwells (Eds.), Handbook of language and communication: diversity and change (pp. 211-240). Berlin, Germany: DeGruyter.

Ríos Ávila, R. (1995). Puerto Rico desde el cielo. Madrid, España: Litofinter.

Rivera Ramos, E. (2007). American colonialism in Puerto Rico: the judicial and social legacy. Princeton, New Jersey: Markus Wiener Publishers.

Rivera Ramos, E. (2015). The Insular Cases: what is there to reconsider? In G. L. Neuman \& T. Brown-Nagin, Reconsidering the Insular Cases: the past and future of the American Empire (pp. 29-38). Cambridge, MA: Harvard Law School.

Rodríguez Bou, I. (1984). Crisis del vernáculo en Puerto Rico: hallazgos y sugerencias. Boletín de la Academia Puertorriqueña de la Lengua Espanñola, 12(1), 5-26.

Rodríguez Galarza, M. I. (1997). The sociopsychological, political, and cultural context of second language instruction in Puerto Rico and student's perceptions and attitudes toward English. (Ph. D. dissertation). The Pennsylvania State University.

Rúa, P. J. (1992). La encrucijada del idioma: ensayo en torno al inglés oficial, la defensa del español criollo y la descolonización puertorriqueña. San Juan, Puerto Rico: Instituto de Cultura Puertorriqueña.

Schweers, W. \& Vélez, J. A. (1992). To be or not to be bilingual in Puerto Rico. TESOL Journal, 2(1), 13-16.

Shenk, E. (2015). El engañol y el cuco: metaphors in the nexus between language and status in Puerto Rico. Journal of Language and Intercultural Communication, 15(3), 324-340.

Silén, J. A. (1993). Historia de Puerto Rico. San Juan, Puerto Rico: Distribuidora de libros.

Torres González, R. (2002). Idioma, bilingüismo y nacionalidad: la presencia del inglés en Puerto Rico. Río Piedras, Puerto Rico: Editorial de la Universidad de Puerto Rico.

Torruella, J. R. (2015). The insular cases: a declaration of their bankruptcy and my Harvard pronouncement. In G. L. Neuman \& T. Brown-Nagin (Eds.), Reconsidering the Insular Cases: the past and future of the American Empire (pp. 61-76). Cambridge, MA: Harvard Law School.

Trías Monge, J. (1999). Puerto Rico: las penas de la colonia más antigua del mundo. Río Piedras, Puerto Rico: Universidad de Puerto Rico. 
Melvin González-Rivera. Language Attitudes Towards Spanish and English in Puerto Rico

United States Congress. (n. d.). Constitution of the United States. Retrieved from https://constitution.congress.gov/ constitution/

Valdez, J. (2016). The battleground of metaphors: language debates and symbolic violence in Puerto Rico (1930-1960). Journal of Historical Sociolinguistics, 2(1), 1-25.

Vélez, J. A. (2000). Understanding Spanish-language maintenance in Puerto Rico: political will meets the demographic imperative. International Journal of the Sociology of Languages, 142(3), 5-24.

Vaughan, G. M. \& Hogg, M. (2004). Social Psychology. (4 ed.). Harlow, UK: Pearson Education. 